\title{
Iono-molecular Separation with Composite Membranes IV. Mono-nitrophenol's pervaporation through polysulfone composite membranes
}

\author{
HUSSAM NADUM ABDALRAHEEM AL ANI ${ }^{1,2}$, ANCA MARIA CIMBRU ${ }^{1}$, ION SPIRIDON DIN ${ }^{1}$, SZIDONIA KATALIN TANCZOS ${ }^{1,3}$, \\ ION MARIUS NAFLIU', ADRIANA CUCIUREANU4* \\ ${ }^{1}$ Politehnica University of Bucharest, Faculty of Applied Chemistry and Material Science, Analytical Chemistry and Environmental \\ Engineering Department,1-7 Gheorghe Polizu Str., 01106, Bucharest, Romania \\ ${ }^{2}$ Institute of Technology- Baghdad, Foundation of Technical Education in Iraq \\ ${ }^{3}$ Sapientia University, Liberty Str., 500104, Miercurea Ciuc, Romania \\ ${ }^{4}$ National Institute for Research and Development for Industrial Ecology -ECOIND, 71-73 Drumul Podul Dambovitei Str., 060652, \\ Bucharest, Romania
}

In this paper, were study the pervaporation of mono-nitrophenols in a laboratoryinstallation of the Membrane, Materials, and Membrane Processes Group of the Polytechnic University of Bucharest, from aqueous synthetic solutions, to composite membranes with polysulfone matrix (PSf) and nanometric inclusions: Polyaniline (PANI), carbon nanotubes (CNT), magnetic nanoparticles (MNP) and sulfonated polyetheretherketone (PEEKS). Tests carried out over $144 \mathrm{~h}$ at a pressure of $100 \mathrm{~mm} \mathrm{Hg}$ or $5 \mathrm{~L} / \mathrm{min}$ air flow at $25^{\circ} \mathrm{C}$ and $\mathrm{pH} 7$ of the feed solution show that vacuum pervaporation is better than vacuum. The more advanced composite membranes are those with sulfonated polyether-ether cellulose (PSf-PEEK-S) and polyaniline (PSf-PANI) ionizers. The results of airborne pervaporation show that composite membranes (PSf-PEEK-S and PSf-PANI) present a marked difference in flux for the mono-mono-nitrophenol isomers, which could also be found in a technically exploitable selectivity. Thus, in the case of the PSf-PEEK-S composite membrane, the mono-nitro-phenol streams decrease in the order: $\mathrm{m}-\mathrm{C} 6 \mathrm{H} 5 \mathrm{NO} 3>\mathrm{O}-\mathrm{C}_{6} \mathrm{H}_{5} \mathrm{NO}_{3}>\mathrm{p}-\mathrm{C}_{6} \mathrm{H}_{5} \mathrm{NO}_{3}$, while for the PSf-PANI composite membrane the order is $\mathrm{O}_{-} \mathrm{C}_{6} \mathrm{H}_{5} \mathrm{NO}_{3}>\mathrm{m}-\mathrm{C}_{6} \mathrm{H}_{5} \mathrm{NO}_{3}>\mathrm{p}-\mathrm{C}_{6} \mathrm{H}_{5} \mathrm{NO}_{3}$. At the same time, it is noted that the PSfPEEK-S composite membrane performance is superior during operation, but shows the opposite of the more pronounced drop.

Keywords: composite membranes, pervaporation, mono-nitrophenol's separation, membrane processes

Composite membranes with polysulfone matrix were previously intensively used on baro-membrane processes [1-5]. In the other hand, pervaporation is one of the most promising and less validated industrial membrane separation processes [6-8]. Although seemingly technically and economically deficient for the separate substances to undergo a phase transformation, pervaporation is a membrane process that combines membrane permeation with vaporization in a collector compartment (fig. 1).

Pervaporation is a membrane technique, in which a mixture of liquid is separated by partial vaporization through a selective non-porous membrane $[9,10]$.

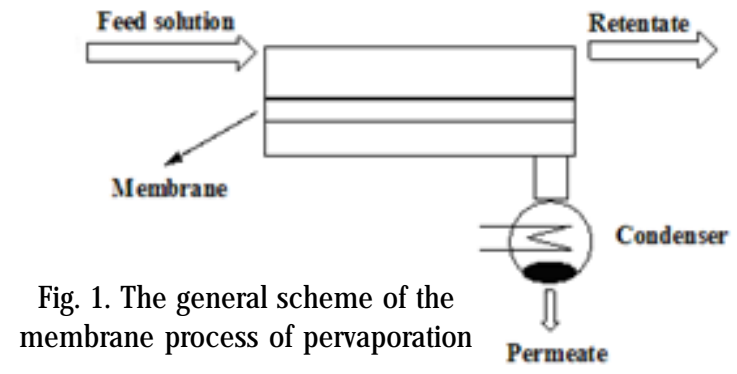

The driving force for mass transfer through the membrane is achieved by applying a partial pressure on the side of the membrane, through which the permeate vapor passes to be condensed higher than their corresponding partial pressures in the separated mixture [11,12].

Mass transfer through the membrane can be divided into three successive stages [13-15]:
- selective absorption into the membrane at the top of the membrane;

- selective diffusion through the membrane;

- desorption in a vapor phase on the membrane side, through which the permeate vapor passes to be condensed.

If the permeation through the membrane is limited by the solubility of the separated compound in the membrane and then its diffusion from the feed compartment to the collection chamber, the vaporization can be performed in several variants (fig. 2 a-f) [16-20]:

a) Vacuum-driven pervaporation;

b) Pervaporation driven by the temperature gradient;

c) Pervaporation with conveying gas;

d) Pervaporation with non-condensed and immiscible transport;

e) Conveyable miscellaneous transport;

f) Two-phase pervaporation of the permeate and partially recirculated.

In a limited case, the collection of the permeate compound is done in a collecting compartment containing an extractor, but this process has been called pertraction (combining permeation with extraction) [18-21].

Sure, the framing of the membrane process variants in the field of pervaporation is related to the fact that the separated substance solubilizes and diffuses through the membrane molecule by molecule, which is similar to vaporization $[21,22]$.

However, the only process involving vaporization of the separated compound, even in the membrane pores, is membrane distillation [23-25]. 


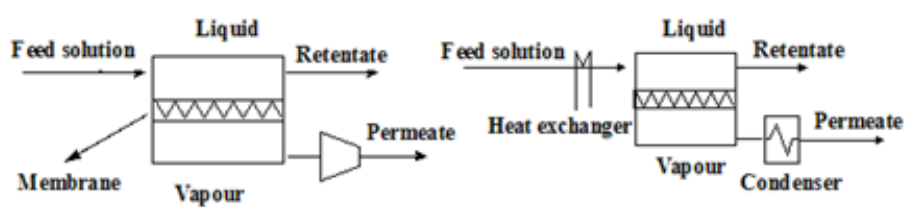

a b

Fig. 2. Diagrams of the principle of the membrane's process of pervaporation: a) vacuum-driven pervaporation;

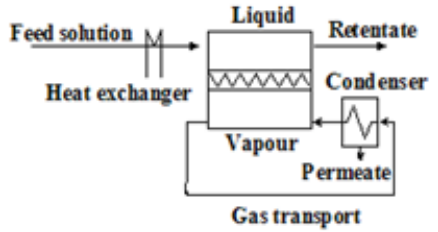

c
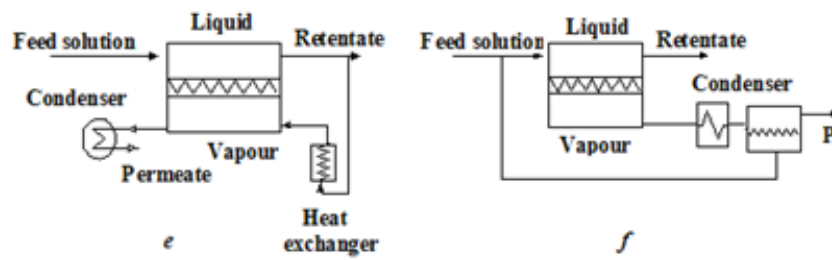

$f$

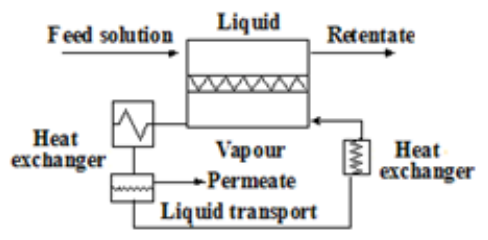

$d$

b) pervaporation driven by the temperature gradient;

c) pervaporation with transporting gas; d) pervaporation with non-condensed and immiscible transport;

(e) condensation-shiftable transport pervaporation; f) two-phase permeate pervaporation and partially recirculated
In classical pervaporation, the membrane polymeric material constituted the restrictive element of the conferid process, both the selection (by the solubility of the target substance in the polymer) and the permeate productivity or flow (by the diffusion coefficient of the species to be separated by the polymer) [25-27].

Since the beginning of the development of the pervaporation, Neel and Aptel, the parents of the process, presented several variants of membrane materials and organic compounds to be separated (table 1) [26, 27].

Most applications of pervaporation are related to the separation of azeotrope mixtures, with particular emphasis on obtaining absolute ethanol [26-28].

In the last two decade, environmental applications have been more and more contrived, with more organic chemicals with arguably polluting or toxic potential being the subject of pervaporation research [29-31].

From this point of view, the phenol and its derivatives form a group of organic compounds with arguably toxic potential for both environmental studies and membrane research on pervaporation [32,33].

In this paper, were study the pervaporation of mononitrophenols in a laboratory installation of the Membrane, Materials, and Membrane Processes Group of the Polytechnic University of Bucharest, from aqueous synthetic solutions, to composite membranes with polysulfone matrix (PSf) and nanometric inclusions: Polyaniline (PANI), carbon nanotubes (CNT), magnetic nanoparticles (MNP) and sulfonated polyetheretherketone (PEEK-S).

\section{Experimental part}

Materials and methods

Preparation of the composite polymer system

The amount of the polymer (PSf-Udel), for the 14\% concentration, was gradually introduced under stirring (magnetic stirrer) into the lid provided with a lid containing the amount of solvent (NMP-Merck) (in the proportions set). Stirring was continued until complete dissolution of the polymer [34-36].

Following the dissolution step of the polysulfone polymer in the solvent, the adjuvants needed to obtain the composites: carbon nanotubes (CNT) [35-37] were added in a concentration of $10 \%$ to the polymer by ultrasonography for 4 hours in the Branson 1510 ultrasonic bath. polyaniline (PANI) [1,2], magnetic nanoparticles (MNP) [1-3] or sulfonated polyetheretherketone (PEEK-S) [2].

The preparation of the desired composite polymer system, depending on the adjuvant involved, was achieved within $4 \mathrm{~h}$ [35-40].

The obtained composite system was filtered on a Sartorius device equipped with a stainless steel wire sieve with a $40 \mu \mathrm{m}$ square mesh side. This operation is aimed at removing the undiluted solid impurities (gels or agglomerates), which negatively influence the film coating process (the appearance of linear defects on the membrane surface) and implicitly the physico-mechanical characteristics of the membrane [36].

Finally, practically prior to film coating, the polymeric system undergoes deaeration in order to remove the embedded gases in the dissolution process. The gas bubbles in the polymer solution can lead to discontinuities and implicit defects in the film coating process, reflected in holes and microphyses on the surface of the membrane. The deaeration was performed by passing the solutions into a vessel connected to a vacuum source (preliminary vacuum pump) $[37,38]$.

The de-aerated polymer systems were subsequently stored in hermetically sealed containers for use in the process of making the composite membranes.

\section{Formation of membranes}

A determined quantity of polymeric system, $7 \mathrm{~mL}$, is deposited on a teflon support, and with a chromatic scroll is expanded to a standard thickness of $200 \mu \mathrm{m}$. The polymer film deposited on the spectral or Teflon glass is immersed in the specially prepared coagulation bath [39]. Polysulfone membranes or polysulfone-adjuvant composites are obtained (figs $3 a-e)$.

\section{Characterisation of membranes}

The obtained composite membranes were washed with a 1: 1 solution of water: methanol. For hydrodynamic tests, the membrane should be washed by remaining in distilled water for 24 hours. For dry membranes characterisation, the membrane is removed from the methanol solution and dried in a vacuum oven at $60^{\circ} \mathrm{C}$ for $4 \mathrm{~h}$. Membrane samples 


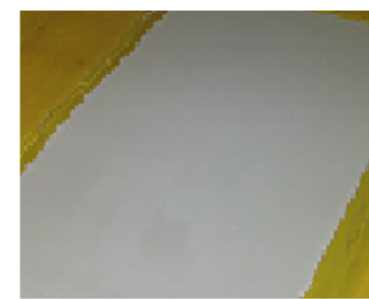

$a$

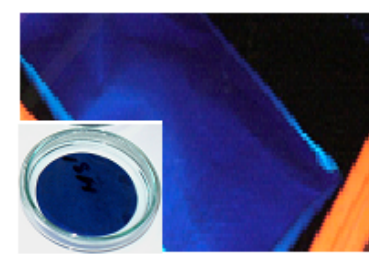

c

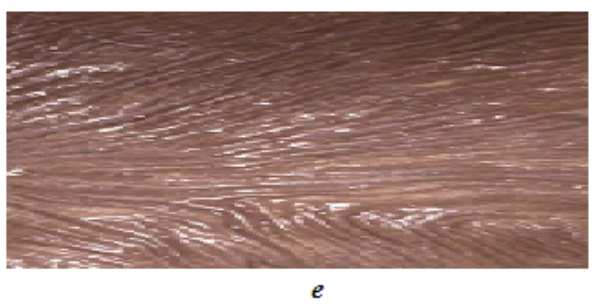

Fig. 3. Composite membranes with polysulfone matrix (PSf) (a), and nanometric inclusions: sulfonated polyetheretherktone (PEEK-

S) (b), polyaniline (PANI) (c), carbon nanotubes (CNT) (d), magnetic nanoparticles (MNP) (e)

(4.8 $\mathrm{cm}$ discs) are transmitted by characterisation [4042].

The series of membranes were investigated morphologically by Electronic Balloon Microscopy (SEM) using the Hitachi S 4500 FESEM [35-38, 41,42].

The images obtained by the scanning electron microscopy technique allow to highlight the surface porosity (at the membrane-support interface-fig. 4 a) and the asymmetric structure of the membrane (the thickness of the superficial active layer of the macroporous support layer, fig. $4 b)$.

The thermal behaviour of the polymeric system characteristic of the composite membrane (thermal stability, respectively degradation of the polymeric system) was highlighted by thermogravimetric analysis (TGA). The investigation method was based on the mass loss analysis of a composite material sample when heated at a given, constant $\left(10^{\circ} \mathrm{C} / \mathrm{min}\right)$ speed until the degradation process was complete (mass remains constant with temperature rise) (fig. 4c). Thermogravimetric analysis was performed in an inertnitrogen atmosphere using a Thermogravimetric Analyzer TGA Q5000 - TA Instruments Inc.

The change in sample mass during the temperature program is closely related to the physico-chemical transformations in the sample.

In order to characterize structurally obtained composite polymeric membranes, the Camspec UV-Vis type apparatus, equipped with an analysis system, computational system, visualisation system and information transcription system was used (fig. 4d).

Pervaporation of the mono-mono-nitrophenol solution

Synthetic mono-mono-mono-nitrophenol solution (SigmaAldrich), with a concentration of $2000 \mathrm{ppm}$, is introduced into a laboratory facility for vacuum pervaporation $(100 \mathrm{mmHg}$ ) or a controlled flow of nitrogen (5L/min), which ensures vaporization in the cell. Synthetic aqueous mono-mono-nitrophenols in the feed are periodically analyzed (CAMSPEC Spectrometer) [43-45].

The pervaporation installation has a main module (fig. 5) in which five types of membranes (identical or different) can be used, which simplifies considerably the study of the process and reduces the number of individual experiments [46].

Permeate mass flux ( $\mathrm{J}$ ) were determined based on the permeate measured, equation (1), and concentrate analysis, equation (2), over a given time interval [46-48]:

$$
J=\frac{M}{S \cdot t} \quad\left(\mathrm{mg} / \mathrm{m}^{2} \mathrm{xh}\right)
$$

where : $M=$ mono-nitrophenol permeate mass $(\mathrm{mg})$

$\mathrm{S}=$ The effective surface area of the membrane $\left(\mathrm{m}^{2}\right)$

$t=$ The time required to collect the permeate mass $(h)$

$$
R=\frac{C_{k}-C_{p}}{C_{k}} \cdot 100(\%)
$$

where $\mathrm{Ck}$ and $\mathrm{Cp}$ denote the mono-nitrophenol concentration $(\mathrm{mg} / \mathrm{L})$ in retentate and permeate, respectively.

\section{Results and discussions}

Phenol pervaporation is a challenge for engineers, not only because their separation from aqueous effluents contributes to the purification of water, but also because after the process, it is possible to reuse the phenol in concentrated or even pure state [49-52 ].

Then again, phenol pervaporation is important and interesting for the researchers because the process can be driven both by the operational parameters: the $\mathrm{pH}$ of the solution, the initial concentration of the phenols, the working temperature and the downstream pressure, as well as, the characteristics of the membrane used and the technical way of operating [52,53].

In this work, the attention was focused on the importance of membrane material, benefiting from the advantage of the facility that allows simultaneous operations with five different membranes, in the same pervaporation mode [1-3,54 ].

The morphostructural characteristics of the tested membranes are shown in figure 4.

From the electron microscopy images (fig. 4a), the compactness, thickness and size of the composite membrane pores are highlighted by the presence of both nanoparticles (PSF-MNP) and polyaniline (PSf-PANI) and carbon nanotubes (PSf-CNT). Also, remarkable morphostructural differences are found in the sulfonated polyetherether-cellulose (PSf-PEEK-S) composite membrane, compared to the polysulfone membrane (PSf) used as a reference. Thermal analysis (fig. 4b) and IR spectra (fig. 4c) complete the characteristics of meprazole, used in mono-mono-nitrophenol pervaporation assays.

Porosimetry data indicates a total porosity of more than $70 \%$, with higher values for the sulfonated polyethylene terephthalate (PSf-PEEK-S) and polyaniline (PSf-PANI) composite membrane.

Differences in FTIR spectra and heat analysis charts, although not spectacular, allow correlations with the separation performance in the pervaporation process of mono-mono-nitrophenols.

The properties of mono-mono-nitrophenols, which may be important for pervaporation through the chosen composite membranes, are shown in table 1. 


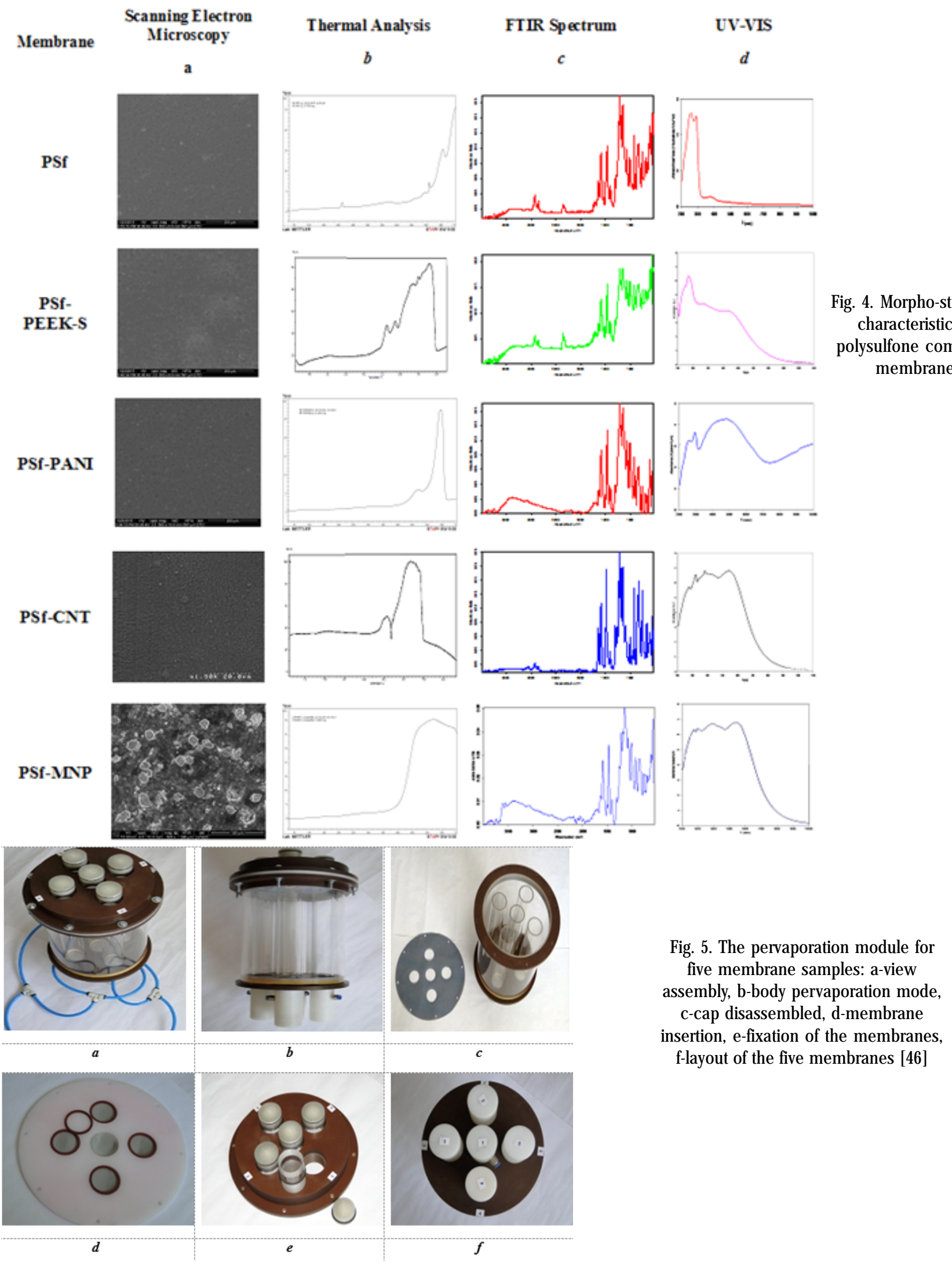

Among the characteristics of mono-nitrophenols, attention is paid to the melting temperature of o-mononitrophenol and the boiling point of m-mono-nitrophenol, which are lower than the other isomers. During the process, the difference in acidity of m-mono-nitrophenol may be important over the other two mono-mono-nitrophenols.

Initial paternity tests of mono-nitrophenols $(1000 \mathrm{mg} / \mathrm{L}$ / mixture of mono-nitrophenols in the feed solution) aimed at choosing the operating mode: vacuum pervaporation (fig. 6a) or airborne pervaporation (fig. 6b).
The data obtained (fig. 6) reveals the superiority of the pervaporation operation in the air stream to the vacuum, the mono-nitrophenol streams, being higher for all the tested membranes.

The polyether-ether-sulfonated (PSf-PEEK-S) and polyaniline (PSf-PANI) composite membranes have superior performance to those with magnetic particles (PSf-MNP) or carbon nanotubes (PSf-CNT).

A particular case consisted of the PSf-PEEK-S composite membrane, whose flux decreases more drastically, during operation than the other membranes. An explanation of 


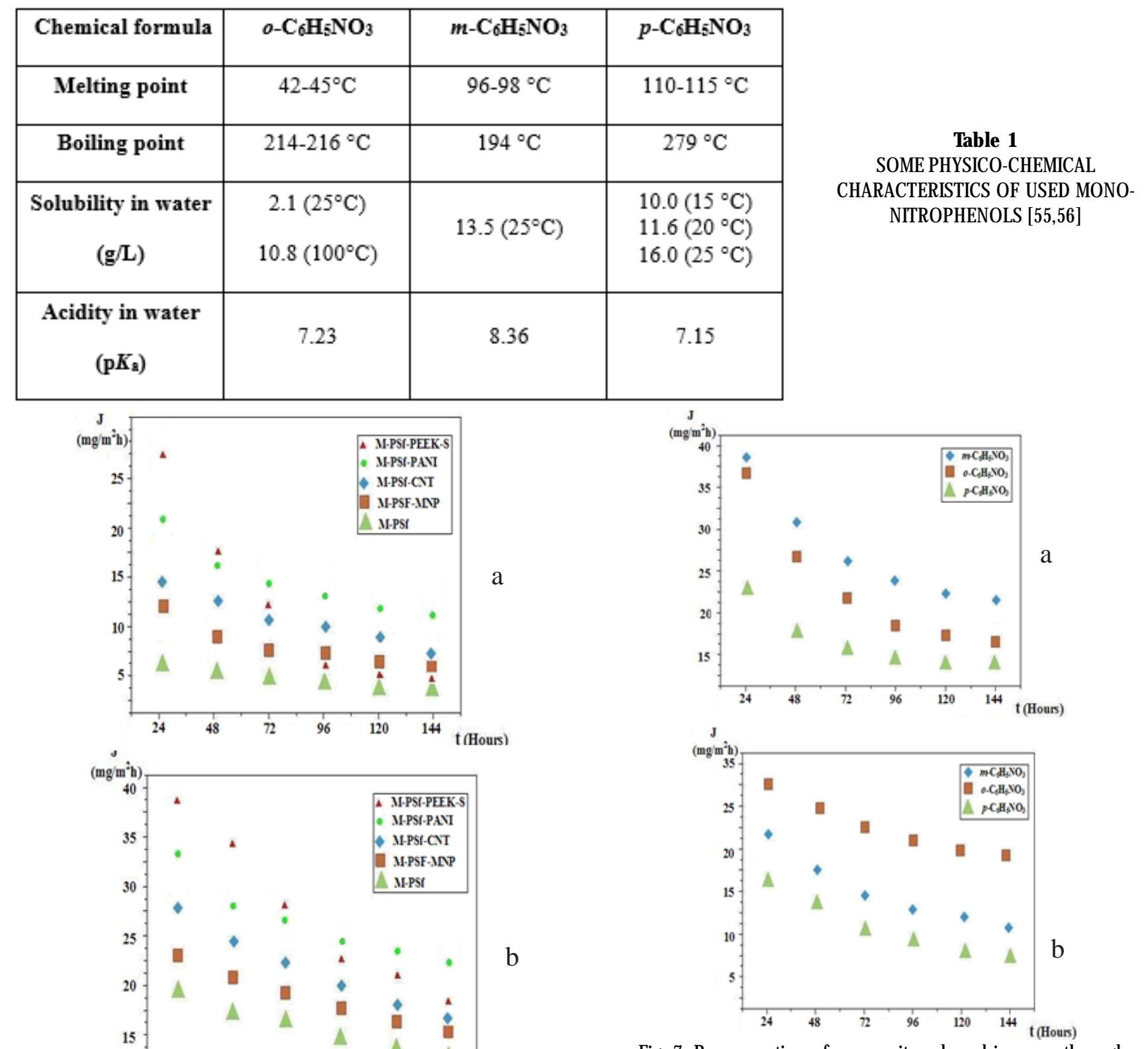

Fig. 7. Pervaporation of mono-nitro-phenol isomers through composite membranes PSf-PEEK-S (a) si PSf-PANI (b)

Fig. 6. Pervaporation of mono-nitrophenols depending on the mode of operation: vacuum pervaporation ( $\boldsymbol{a}$ ) by air entrainment (b)

this behavior could be the drying of the membrane downstream, especially in the case of vacuum coding (fig. $6 a$, compared with $6 \mathrm{~b}$ ).

Tests carried out over $144 \mathrm{~h}$ at a pressure of $100 \mathrm{~mm} \mathrm{Hg}$ or $5 \mathrm{~L} / \mathrm{min}$ air flow at $25^{\circ} \mathrm{C}$ and $\mathrm{pH} 7$ of the feed solution show that vacuum pervaporation is better than vacuum. The more advanced composite membranes are those with sulfonated polyether-ether cellulose (PSf-PEEK-S) and polyaniline (PSf-PANI) ionizers.

These two types of composite membranes (PSf-PEEK$S$ and PSf-PANI) were used in the pervaporation experiments of the mono-nitro-phenol isomers (fig. 7a and b).

The results of airborne pervaporation show that composite membranes (PSf-PEEK-S and PSf-PANI) present a marked difference in flux for the mono-mononitrophenol isomers, which could also be found in a technically exploitable selectivity.

Thus, in the case of the PSf-PEEK-S composite membrane, the mono-nitro-phenol streams decrease in the order of:

$m-\mathrm{C}_{6} \mathrm{H}_{5} \mathrm{NO}_{3}>0-\mathrm{C}_{6} \mathrm{H}_{5} \mathrm{NO}_{3}>p-\mathrm{C}_{6} \mathrm{H}_{5} \mathrm{NO}_{3}$ (fig. 7a) $0-\mathrm{C}_{6} \mathrm{H}_{5}^{6} \mathrm{NO}_{3}>\quad m-\mathrm{C}_{6}^{6} \mathrm{H}_{5}^{5} \mathrm{NO}_{3}^{3}>p-\mathrm{C}_{6}^{6} \mathrm{H}_{5}^{5} \mathrm{NO}_{3}^{3}$ (fig. 7b).

At the same time, it is observed that the PSf-PEEK-S composite membrane performance is superior during operation, butshows the opposite of the more pronounced decrease (fig. $7 a$ and $b$ ).

\section{Conclusions}

In this paper, mono-nitrophenol pervaporation was studied through polysulfone matrix composite membranes (PSf) and inclusions of: polyaniline (PANI), carbon nanotubes (CNT), magnetic nanoparticles (MNP) and pelletereterketone sulfonate (PEEK-S).

Attention was focused on the influence of membrane material on the pervaporation of mono-mono-nitrophenols, benefiting from the advantage of the facility that allows simultaneous operations with five different membranes, in the same pervaporation mode.

Tests carried out over 144 hours at a pressure of 100 $\mathrm{mm} \mathrm{Hg}$ or $5 \mathrm{~L} / \mathrm{min}$ air flow at $25^{\circ} \mathrm{C}$ and $\mathrm{pH} 7$ of the feed solution show that vacuum pervaporation is better than vacuum. The more advanced composite membranes are those with sulfonated polyether-ether cellulose (PSf-PEEKS) and polyaniline (PSf-PANI) ionizers. 
The results of airborne pervaporation show that composite membranes (PSf-PEEK-S and PSf-PANI) present a marked difference in flux for the mono-mononitrophenol isomers, which could also be found in a technically exploitable selectivity.

Thus, in the case of the PSF-PEEK-S composite membrane, the mono-nitro-phenol streams decrease in the order: $m$-C6H5NO3> $-\mathrm{C}_{6} \mathrm{H}_{5} \mathrm{NO}_{3}>p-\mathrm{C}_{6} \mathrm{H}_{5} \mathrm{NO}_{3}$, while for the PSf-PANI composite membrane the order is o$\mathrm{C}_{6} \mathrm{H}_{5} \mathrm{NO}_{3}>m-\mathrm{C}_{6} \mathrm{H}_{5} \mathrm{NO}_{3}>p-\mathrm{C}_{6} \mathrm{H}_{5} \mathrm{NO}$. At the same time, it is noted that the PSf-PEEK-S composite membrane performance is superior during operation, but shows the opposite of the more pronounced drop.

\section{References}

1.RIKABI, A.A.K.K., CUCIUREANU, A., CHELU, M., MIRON, A.R., ORBECI, C., POPA, A.G., CRACIUN, M.E., Rev. Chim. (Bucharest), 66, no. 8, 2015, p. 1093

2.RIKABI, A.A.K.K., BALABAN (CHELU), M., HARABOR, I., ALBU, P.C., SEGARCEANU, M., NECHIFOR, G., Rev. Chim. (Bucharest), 67, no. 9, 2016, p. 1658

3.RIKABI, A.A.K.K., NECHIFOR, A.C., MOHAMMED, T. J., OPREA, O., MIRON, A.R., SEGARCEANU, M., VAIREANU, D.I., Rev. Chim. (Bucharest), 67, no. 9, 2016, p. 1489

4.AL ANI, H.N.A., CIMBRU, A.M., TRISCA-RUSU, C., TANCZOS, S.K.., CUCIUREANU, A., NECHIFOR, A.C., Rev. Chim. (Bucharest), 68, no. 2, 2017, p. 203

5.AL ANI, H.N.A., CIMBRU, A.M., TANCZOS, S.K.., DIN, I.S., CUCIUREANU, A., NAFLIU, I.M., NECHIFOR, G., Rev. Chim. (Bucharest), 68, no. 3, 2017, p. 427

6.R.Y.M. HUANG, Science and Technology Series 1, Pervaporation Membrane Separation Processes, Elsevier, Amsterdam, 1991

7.NEEL, J. Pervaporation, Tech \& Doc., Lavoisier, Paris (in French), 1997

8.VAN DER BRUGGEN, B., DAEMS, B., WILMS, D., VANDECASTEELE, C., Separation and Purification Technology, 22-23, 2001, p. 519

9.CABASSO, I., Ing. Eng. Chem. Prod. Res. Dev., 33, 1983, p. 313-319 10.MULDER, M.H.V., SMOLDERS, C.A., J. Membr. Sci., 17, 1984, pp. 289 11.MULDER, M.H.V., FRANKEN, A.C.M., SMOLDERS, C.A., J. Membr. Sci., 23,1985,pp. 41

12.SCHIMDT, A., UHLRICH, M., Chem. Ing. Tech., 62,1990, p. 43 13.WIJ MANS, J.G., BAKER, R.W., J. Membr. Sci., 1,1995, p.107 14.BINNING, R.C., LEE, R.J., JENNINGS, J.F., MARTIN, E.C., Ind. Eng. Chem., 53,1961, p. 45

15.PAUL, D.R., EBRA-LIMA, O.E., J. Apll. Polym. Sci., 15, 1971, p.1299 16.PAUL, D.R., J. Polym. Sci. Polym. Phys. Ed., 12, 1974, p. 1221

17.CABASSO, L., JAGUR-GRODZINSKI, L., VOFSI, D., J. Appl. Polym. Sci., 18, 1974, p. 2137

18.MANDAL, M.K., BHATTAKCARYA, P.K., Sep. and Purif. Tech.,61, 2008, p. 332

19.J ONQUIERES, A., CLEMENT, R., LOCHON, P., NEEL, J ., CHRETIEN, B., DRESCH, M., J. Membr. Sci., 206, 2002, p. 87

20.CHEN, J., LI, J., QI, H., YE R.,, CHEN, C., Appl. Biochem. Biotechnol., 160, 2010, p. 486

21.HAN, B., LI, J., CHEN, C., WICKRAMASINGHE, R., Desalination, 145, no. 1-3, 2002, p. 187

22.LI, J., CHEN, C., HAN, B., PENG, Y., J. Membr. Sci., 203, 2002, p. 127 23.MANDAL, M.K., BHATTAKCARYA, P.K., Sep. and Purif. Tech., 61, 2008, p. 333

24.OHSHIMA, T., KOGAMI, Y., MIYATA, T., URAGAMI, T., J. Membr. Sci., 260, 2005, p. 156

25.CASSANO, A., FIGOLI, A., TAGARELLI, A., SINDONA, G., DRIOLI, E., Desalination 186, 2006, p. 121

26.NEEL, J., APTEL, P., CLEMENT, R., Desalination, 53, 1965, p. 297
27.APTEL, P., CHALLARD, N., CUNY, J., NEEL, J., J. Membr. Sci., 1, 1976, p. 271

28.PAUL, D.R., J. Polym. Sci. Polym. Phys. Ed., 12, 1974, p. 1221

29.SUN, O., YANG, L., Water Research, 7, 2003, p. 315

30.BUSCA, G., BERARDINELLI, S., RESINI, C., ARRIGHI, L., J. Hazard. Mat. , 160, 2008, p.265

31.GUPTA, T., PRADHAN, N.C., ADHIKARI, B., J. Membr. Sci., 217, no.1-2, 2003, p. 43

32.NOW ORYTA, A., TRUSEK-HO£OW NIA, A., MIELCZARSKI, S., KUBASIEWICZ-PONITKA, M., Desalination , 198, 2006, p. 191

33.JIE, Y., YANG, S., ZIWEI, D., BIAOMING, L., ZHONGWEI, W., VAN AGTMAAL, S., CHUNHUI, F., BANGJUN, H., J ournal of Membrane and Separation Technology, 2, 2013, p. 148

34.KESTING, R.E., Synthetic polymeric membranes: a structural perspective, Wiley-Interscience, New York, 1985

35.POPESCU, G., NECHIFOR, G., ALBU, B., LUCA, N., Rev. Roum. Chim., 34, no. 2, 1989, p. 577

36.CUCIUREANU, A., BATRINESCU, G., BADEA, N.N., RADU, D.A., NECHIFOR, G., Mat. Plast., 47, no. 4, 2010, p. 416

37.NECHIFOR, G., VOICU, S.I., NECHIFOR, A.C., GAREA, S., Desalination, 241, no. 1-3, 2009, p. 342

38.VOICU, S.I., STANCIU, N.D., NECHIFOR, A.C., VAIREANU, D.I., NECHIFOR, G., Romanian J ournal of Information Science and Technology, 12, no.3, 2009, p. 410

39.VOICU, S.I., ALDEA, F., NECHIFOR, A.C., Rev. Chim. (Bucharest), 61, no. 9, 2010, p. 817

40.VOICU, S.I., ALDEA, F., RADUT, M., NECHIFOR, G U.P.B. Sci. Bull., Series B, Vol. 70, no. 3, 2008, p. 39

41.POPA, G.A., POPA, (ENACHE), D.F., SLAVE(CLEJ), D.D., DIN, I.S., MIREA, C.M., CIOCANEA, A., Rev. Chim. (Bucharest), 68, no. 1, 2017, p. 6

42.NECHIFOR, G., ALBU, B.G., RATA, D., POPESCU, G., Rev. Chim. (Bucharest), 47, no. 3, 1996, p. 260

43.DIACONU I., GîRDEA R., CRISTEA C., NECHIFOR G., RUSE E., Totu E. E., Rom Biotech Lett, 15, no. 6, 2010, p. 5703

44.DIACONU I., ABOUL-ENEIN H.Y., AL-OMAR M.A., NECHIFOR G., RUSE E., BUNACIU A..A, TOTU. E.E, Arab. J. Chem., 4, no. 1, 2011, p. 99

45.DIACONU I., NECHIFOR G., NECHIFOR A.C., RUSE E., TOTU, E.E., UPB.Sci.Bull. Serries B, 71, no.4, 2009, p. 61

46.SAVA (POPA), S., PhD Thesis, 2013, University Politehnica of Bucharest, Romania

47.BATRINESCU, G., CONSTANTIN, M.A., CUCIUREANU, A., NECHIFOR, G., Polymer Engineering and Science, 54, no. 7, 2014, p. 1640, DOI: 10.1002/ pen.23707

48.NECHIFOR, G., LUCA, N., POPESCU, G., NECHIFOR, M., Rev. Roum. Chim., 34, no. 11-12, 1989, p. 2047

49.SINGH, D.K., SRIVASTAVA, B., Journal of Scientific \& Industrial Research, 61, 2002, p. 208

50.JIANG, Zhen-mao, LI, Ai-min, CAI, Jian-guo, WANG, Chun, ZHANG, Quan-xin, Journal of Environmental Sciences , 19, 2007, p. 135 51.WAGNER, K., SCHULZ, S., J. Chem. Eng. Data, 46, 2001, p. 322 52.G.H. KROPS, C.A. SMOLDERS, Pervaporation membrane separation processes, Elsevier, NY,1991,253

53.ORBECI, C., UNTEA, I., NECHIFOR, G., SEGNEANU, A.E., CRACIUN, M.E., Separation and Purification Technology, 122, 2014, p. 290

54.SERBAN, B., RUSE, E., MINCA, M., PASARE, J., NECHIFOR, G., Rev.Chim. (Bucharest), 51, no. 4, 2000, p. 249

55.NECHIFOR, A.C., RUSE, E., NECHIFOR, G., SERBAN, B., Rev. Chim. (Bucharest), 53, no. 1, 2002, p. 20

56.DIACONU, I., ZAHARIA, I., RUSE, E., NECHIFOR, G., Dig. J. Nanomater. Bios., 7, no. 3, 2012, p. 1303

Manuscript received: 15.12 .2016 